\title{
The Effect of Studying Flight Training Materials utilizing Encoding Techniques on Situational Awareness Capabilities of Students in PPL Training
}

Jeong Yoon Moon", Jang Ryong Lee

\begin{abstract}
The pilot's aeronautical decision-making during the flying greatly affects flight safety, and the importance of situational awareness has been greatly emphasized as a prerequisite for making the right decision. This is the reason why more research and interests are needed to help students entering the pilot training program develop excellent situational awareness from the initial stage of training. Situational awareness is closely related to long-term memory activities in human information processing, and pedagogy and cognitive psychology have emphasized the encoding techniques as an effective long-term memory method. This study was conducted to confirm whether pilot students' using the encoding techniques to learn flight education materials in the early stage of their training at domestic universities has a positive effect on improving their situational awareness.
\end{abstract}

Key Words : Encoding(부호화), Long-Term Memory(장기기억), Flight Training Maretials(비행교육 자료), PPL Training(초기 조종교육), Situational Awareness(상황인식)

\section{INTRODUCTION}

According to the Airline Accident Analysis Report by the International Civil Aviation Organization (ICAO) (2018), accidents of the high-risk categories (HRC) accounted for 58\% of all accidents, but they also accounted for 96\% of accidents involving human deaths or $82 \%$ of accidents with destroyed or damaged

Received: 02. Dec. 2020, Revised: 09. Dec. 2020,

Accepted: 14. Dec. 2020

* Graduate Student with a Master's Degree, Department of Aviation Management, Korea Aerospace University

** Professor, Department of Aviation Management, Korea Aerospace University

Corresponding Author E-mail : jrherky@kau.ac.kr Corresponding Author address : 76, Hanggongdaehakro, Deogyang-gu, Goyang-si, Gyeonggi-do, Republic of Korea aircraft. The leading cause of these accidents was a lack of quick and accurate situational awareness and decision-making on a pilot's part. The high-risk category accidents are mainly divided into the Loss of Control in Flight (LOC-I) type and the Controlled Flight into Terrain (CFIT) (ICAO, 2019) type.

Lim, J. G. (2014) also cited human factors, such as pilot's perceptual errors and errors in decision-making, as the leading causes of aviation accidents. He analyzed that the latter accounted for the largest proportion of human factors, arguing that situational awareness errors affect decision-making.

In order to improve situational awareness of abnormal flight conditions, it is necessary to use a method in which student pilots memorize flight-related information well from the training 
stage so that they can retrieve the training materials without any failure during an actual flight (Park S. A. et al., 2006). Lee H. S. (2017) further added that there is an encoding technique as a way to remember information based on the human information processing theory and that this technique should be considered with the method of retrieving encoded information together.

Although many studies on pilot's situational awareness were carried out in the past, few studies have suggested a method of how to reflect these results in pilot education and training (Son, Y. W., 2007).

Therefore, the purpose of this study was to confirm whether making student pilots at domestic universities, who have just begun the pilot training, to learn educational materials in preparation for abnormal flight situations using encoding techniques help improve their situational awareness.

\section{THEORETICAL CONSIDERATION}

\subsection{Situational awareness}

Situational Awareness means one's awareness of a given situation, a concept of how one perceives or interprets the situation he/she is in. It is defined as a cognitive process that serves as the basis for predicting and responding to the current or future situation. (Yang, D. -G., 2017).

Situational awareness is a concept addressed in various disciplines such as healthcare, ground transportation, and marketing. The aviation field has greatly recognized its importance because a lack of pilot's situational awareness was revealed to be the leading cause of aviation accidents since the early 1990s (ICAO, 2018).

Endsley (1995) argued in his study on pilot's situational awareness that the term "situational awareness" was specially adopted to describe a pilot's decision-making process that includes attention beginning from the pilot's mental model regarding the current situation, cognition, and decision-making.

The process of situational awareness can be divided into three stages. The first stage is a perception of cues, which means the perception of the environment surrounding the pilot. The second stage is comprehension, which means a process of integrating perceived information with past experiences and knowledge to create meaning. The third stage is a projection, which includes the establishment of a plan for predicting the future and how to respond to it based on the meanings of the contents understood (Kwon, B. -H., 2007).

\subsection{Information processing and long-term memory}

Memory is a concept created to describe human cognitive abilities, which means one's ability to retain information over time. It refers to a series of mental undertakings or abilities that include activities to store and retrieve information when necessary. (Park S. A. et al., 2006)

Memory is largely divided into short-term memory and long-term memory. Short-term memory refers to a memory that stores information selected from those (sensory information) entered through the sensory organs for a relatively short period (about 30 seconds). Long-term memory refers to a permanently stored memory that is not currently in use but can be used if necessary (Goldstein, 2019). Longterm memory is a place where all the information accumulated by humans, such as general knowledge about objects, technical knowledge, knowledge about linguistic concepts and grammar, images, emotions, and personal experiences, is stored (Anderson, 2018).

Craik and Lockhart (1972) argued that to have a good memory, what level of information processing was performed was important according to the theory of depth of processing. This means no matter how hard one tries to 
remember, if he/she cannot process the information in depth, storing that information into long-term memory is difficult.

As such, previous studies on long-term memory were carried out with a particular focus on how the information is stored, retrieved, and used rather than memory capacity or duration of memory (Park S. A. et al., 2006).

\subsection{Encoding techniques}

Park S. A. et al. (2006) described that when information passes from short-term memory to long-term memory, it goes through the input process of "encoding", calling it the elaboration process and the organization process.

The elaboration process is a process in which the information in long-term memory and new information become connected and integrated. It means creating a new connection between information and deducing the implications of information. The effect of this process is known to be maximized when a learner creates this process on his/her own (Kwon, B.-H., 2007).

The organization process is a process of grouping related items into categories instead of remembering new information as individual facts. It refers to a process that stimulates memory by creating the hierarchical structures and relationships between information, thereby, reducing the total volume of data to be processed (Goldstein, 2019).

On the other hand, Choi, D. -H. (2018) said the imagery was another method of in-depth information processing. She pointed out that the information generated through imagery has perceptual and spatial characteristics, so it is easy to distinguish it from other information and easy to remember as it is subject to lesser interference, helping to remember information if necessary.

\section{RESEARCH DESIGN}

\subsection{Research model}

The knowledge and experience information accumulated by humans is stored in long-term memory and retrieved when necessary. They are the basis for recognizing a given situation (Lee et al., 2006). A pilot also stores the knowledge and experience he/she acquired through training in long-term memory and retrieves and uses them to identify and deal with all kinds of flight situations when necessary (Park S. A. et al., 2006).

Therefore, it is believed that if the pilot can effectively store the training contents in his/her long-term memory, it will help him/her to quickly and accurately assess situations.

Weinstein and Mayer (1986), for instance, argued that the encoding technique was an efficient way to store learned information in long-term memory.

Choi, S. -H. (2011) pointed out that pilot training was generally centered on flight knowledge and mastery of maneuvering skills, while training that reflected factors related to situational awareness was rare to see. For example, Special Table 12 of the enforcement rules of the Aviation Safety Act (2020), which contains contents that must be included in the initial pilot training curriculum in Korea, does not provide a training method that considers situational awareness.

Therefore, this study aims to confirm whether student pilots in the early stage of the training program learning the emergency educational materials where encoding techniques are applied in a way that allows them to store the experiences and knowledge acquired through training in long-term memory and retrieve them when necessary has a positive effect on improving their situational awareness, including situational perception, situational comprehension, and situational projection. The research model installed to achieve this purpose of the study is shown in Fig. 1. 


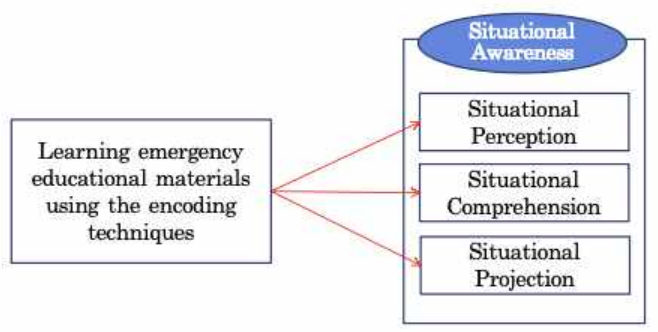

Fig. 1. Research model

\subsection{Research hypotheses}

Based on the research model, the followings are the research hypotheses established to confirm whether pilot students in the initial training program learning emergency measures using the encoding techniques have any effect on improving situational awareness during flying, such as situational perception, situational comprehension, and situational projection.

H1. If pilot students in the initial training program learn about emergency educational materials using the encoding techniques, that will have a positive $(+)$ effect on their situational perception during flying.

H2. If pilot students in the initial training program learn about emergency educational materials using the encoding techniques, that will have a positive $(+)$ effect on their situational comprehension during flying.

H3. If pilot students in the initial training program learn about emergency educational materials using the encoding techniques, that will have a positive (+) effect on their situational projection during flying.

\section{EMPIRICAL RESEARCH}

\subsection{Research subject and sampling}

This study chose students of Aeronautical
Science and Flight Operation major at a domestic university, who are currently enrolled in the Private Pilot License (PPL) program and who have similar age range and educational experiences. PPL program is defined as the certificate course for a private pilot license operated by a specialized educational institution designated under the Aviation Safety Act. According to the data released by the Korea Transportation Safety Authority (2019), about 180 private pilots are annually trained and produced through this program.

To collect the study sample population, research briefing sessions were held and given to 154 student pilots who were currently majored in aeronautical science and flight operation at four domestic universities and enrolled in the PPL program. To confirm their current situational awareness competency level, the first survey (Pre-Test) was conducted among them online.

A total of 80 people among the subjects took the test. The study then randomly selected 40 of the respondents who wished to learn emergency educational materials using the encoding techniques provided by the researcher as the experimental group, while setting the rest as the control group.

The test participants were either 3rd or 4th-year students at a domestic university, and the total flight time of each student ranged from 40 to 80 hours.

Considering these results, the respondents were student pilots in their mid-twenties with similar knowledge and experiences in flying, and it was determined that there was no significant difference in demographics.

\subsection{Assessment tool}

This study used a self-administered questionnaire to assess the situational awareness of PPL student pilots.

As for the questions, the study used a ques- 
tionnaire that was established by Goh and Wiegmann (2002) to assess the pilot's situational awareness, revising some of the sentences to reflect the contents of the PPL curriculum and the idea of situational awareness in the Situation Awareness Rating Technique (SART) developed by Taylor (1989).

\subsubsection{Situational perception assessment}

In order to assess the situational perception, which is the first stage of situational awareness, six questions were constructed based on the questionnaire developed by Goh and Wiegmann (2002) to assess the pilot's situational awareness and by revising some of its phrases to suit the educational content of PPL student pilots. Example questions are as follows: "Based on the flight information (e.g. weather, AIP and others), what do you think is the level of vigilance to maintain the planned flight path?", and "What do you think of the level of vigilance of pilots regarding the possibility of a sudden change in flight situations?"

The answers were measured on a 5-point Likert scale ( $1=$ not at all, $5=$ very much so).

\subsubsection{Situational comprehension assessment}

In order to assess situational comprehension, which is the second stage of situational awareness, six questions were also constructed based on the questionnaire developed by Goh and Wiegmann (2002) and by revising some of its phrases to suit the educational content of PPL student pilots. Example questions are as follows: "What do you think of the pilots' level of perception regarding external conditions (e.g. obstacles or aircraft attitude) that may affect flight safety during flying?, and "What do you think of the pilots' ability to distribute attention during flying?"

The answers were measured on a 5-point Likert scale ( $1=$ not at all, $5=$ very much so).

\subsubsection{Situational projection assessment}

In order to assess the situational projection, which is the third stage of situational awareness, six questions were also constructed based on the questionnaire developed by Goh and Wiegmann (2002) and by revising some of its phrases to suit the educational content of PPL student pilots. Example questions are as follows: "What do you think of the pilots' level of establishment of measures regarding external conditions (e.g. obstacles or aircraft attitude) that affect flying?", and "What do you think about the accuracy of the information obtained by pilots regarding flight situations?"

The answers were measured on a 5-point Likert scale $(1=$ not at all, $5=$ very much so).

\subsection{Research procedure}

This study established a hypothesis through a review of previous studies in order to confirm whether the learning of emergency situation education materials using the encoding techniques has a positive effect on the improvement of situational awareness of PPL student pilots. In order to verify this, the experimental group of student pilots was provided with two learning materials via e-mail, including the situation awareness explanation and videos related to PPL training using the encoding techniques, for eight weeks. After the experiment ended, the second survey (Post-Test) on situational awareness was conducted among both the experimental group and the control group. Also, the same survey was conducted among the expert group consisting of ten flight instructors.

To test the research hypotheses, the following analysis were performed on collected data, such as the 1st survey (Pre-Test), 2nd survey (Post-Test), and expert group responses, using the SPSS24.

First, reliability analysis was conducted to test the reliability and internal consistency of 
the survey questionnaire.

Second, in order to test whether the suitability of the research model and three variables, such as situational perception, situational comprehension, and situational projection, were valid to assess situational awareness, the Kaiser-MeyerOlkin (KMO) test and Bartlett's test were performed as factor analysis to verify the validity of the number of the questions in the assessment tools and sub-items.

Third, an independent sample t-test was conducted to verify whether the learning of emergency education materials using the encoding technique showed a significant difference in situational awareness, which is the main variable, between the experimental group and the control group.

Fourth, in order to confirm whether the difference between the experimental group and the control group that appeared from the t-test results was positive or not, the results of the post-test were compared with the responses of the expert group.

\subsection{Analysis results}

\subsubsection{Reliability analysis}

Based on the results of calculating the Cronbach's alpha coefficients for the three factors of situational awareness in two surveys, namely, situational perception, situational comprehension, and situational projection, the Cronbach's alpha for each factor was found to be 0.7 or above as shown in Table 1 and 2 below. These results indicate good internal consistency and reliability of the measurement tools.

\subsubsection{Validity analysis}

The validity of the three factors of situational awareness in two surveys was examined through the Principal Axis Factoring of factor analysis and Varimax rotation. Among them, the sixth item of the first survey on situational
Table 1. Pre-test reliability analysis

\begin{tabular}{l|c|c}
\hline \multicolumn{1}{c|}{ Assessment tools } & Cronbach's alpha & \# of items m \\
\hline $\begin{array}{l}\text { Situational } \\
\text { perception }\end{array}$ & .910 & 6 \\
\hline $\begin{array}{l}\text { Situational } \\
\text { comprehension }\end{array}$ & .918 & 6 \\
\hline $\begin{array}{l}\text { Situational } \\
\text { projection }\end{array}$ & .933 & 6 \\
\hline
\end{tabular}

Table 2. Post-test reliability analysis

\begin{tabular}{l|c|c}
\hline Assessment tools & Cronbach's alpha & \# of items m \\
\hline $\begin{array}{l}\text { Situational } \\
\text { perception }\end{array}$ & .876 & 6 \\
\hline $\begin{array}{l}\text { Situational } \\
\text { comprehension }\end{array}$ & .925 & 6 \\
\hline $\begin{array}{l}\text { Situational } \\
\text { projection }\end{array}$ & .841 & 6 \\
\hline
\end{tabular}

comprehension and the fifth item of the second survey on situational perception were excluded because they undermined the validity. The factor analysis was conducted with a total of 17 items in both the first and second surveys.

\subsubsection{The first survey (pre-test) independent- samples T-test}

In order to test whether there was a difference in situational awareness capability between the experimental group and the control group before providing emergency situation learning materials using the encoding technique, which is the variable of this study, the first survey (pre-test) was conducted, and the independentsamples $t$-test was performed on its collected data. According to the test results, the $p$-value for all three elements of situational awareness, including situational perception, situational comprehension, and situational projection, was found to be $p 0.05$ or above, indicating that there was no significant difference in the situational awareness capability between the two groups before the provision of learning materials of the encoding technique. 


\subsubsection{The second survey (post-test) inde- pendent-samples T-test}

In order to test whether there was a difference in situational awareness capability between the experimental group and the control group after providing emergency learning materials using the encoding technique, the second survey (posttest) was conducted, and the independent-samples $t$-test was performed on its collected data.

According to the test results, there was no significant difference in the situational perception factor as shown in Table 3, Table 4, and Table 5 below. However, a significant difference was found in one item of situational comprehension and three items of situational projection. In general, it is determined that there is a significant difference when $p<0.05$. In this study, the $p$-value was found to be $p=0.034$ for situational comprehension item 1 , $p=0.011$ for situational projection item 2,

Table 3. Results of post-test on situational perception

\begin{tabular}{|c|c|c|c|c|c|c|}
\hline $\begin{array}{c}\text { Depen- } \\
\text { dent } \\
\text { variable }\end{array}$ & Group & $\begin{array}{l}\# \text { of } \\
\text { sub- } \\
\text { jects }\end{array}$ & $\begin{array}{c}\text { Aver- } \\
\text { age }\end{array}$ & $\begin{array}{l}\text { Standard } \\
\text { deviation }\end{array}$ & $t$ & $p$ \\
\hline \multirow{2}{*}{$\begin{array}{l}\text { Situati- } \\
\text { onal } \\
\text { percep- } \\
\text { tion } 1\end{array}$} & EG & 31 & 3.06 & 1.12 & \multirow[b]{2}{*}{-0.623} & \multirow[b]{2}{*}{0.536} \\
\hline & CG & 27 & 3.26 & 1.26 & & \\
\hline \multirow{2}{*}{$\begin{array}{l}\text { Situati- } \\
\text { onal } \\
\text { percep- } \\
\text { tion } 2\end{array}$} & $\mathrm{EG}$ & 31 & 3.32 & 1.05 & \multirow[b]{2}{*}{-1.050} & \multirow[b]{2}{*}{0.298} \\
\hline & CG & 27 & 3.63 & 1.18 & & \\
\hline \multirow{2}{*}{$\begin{array}{c}\text { Situati- } \\
\text { onal } \\
\text { percep- } \\
\text { tion } 3\end{array}$} & $\mathrm{EG}$ & 31 & 3.16 & 1.37 & \multirow[b]{2}{*}{-0.632} & \multirow[b]{2}{*}{0.530} \\
\hline & CG & 27 & 3.37 & 1.11 & & \\
\hline \multirow{2}{*}{$\begin{array}{c}\text { Situati- } \\
\text { onal } \\
\text { percep- } \\
\text { tion } 4\end{array}$} & EG & 31 & 2.97 & 1.14 & \multirow[b]{2}{*}{-1.270} & \multirow[b]{2}{*}{0.209} \\
\hline & CG & 27 & 3.33 & 1.04 & & \\
\hline \multirow{2}{*}{$\begin{array}{c}\text { Situati- } \\
\text { onal } \\
\text { percep- } \\
\text { tion } 5\end{array}$} & $\mathrm{EG}$ & 31 & 3.26 & 1.09 & \multirow[b]{2}{*}{-0.256} & \multirow[b]{2}{*}{0.799} \\
\hline & CG & 27 & 3.33 & 1.14 & & \\
\hline
\end{tabular}

Table 4. Results of post-test on situational comprehension

\begin{tabular}{|c|c|c|c|c|c|c|}
\hline $\begin{array}{c}\text { Depen- } \\
\text { dent } \\
\text { variable }\end{array}$ & Group & $\begin{array}{l}\# \text { of } \\
\text { sub- } \\
\text { jects }\end{array}$ & $\begin{array}{c}\text { Aver- } \\
\text { age }\end{array}$ & $\begin{array}{l}\text { Standard } \\
\text { deviation }\end{array}$ & $t$ & $p$ \\
\hline \multirow{2}{*}{$\begin{array}{l}\text { Situati- } \\
\text { onal } \\
\text { percep- } \\
\text { tion } 1\end{array}$} & EG & 31 & 3.23 & 1.15 & \multirow{2}{*}{$-2.17^{*}$} & \multirow{2}{*}{0.034} \\
\hline & CG & 27 & 2.85 & 1.03 & & \\
\hline \multirow{2}{*}{$\begin{array}{c}\text { Situati- } \\
\text { onal } \\
\text { percep- } \\
\text { tion } 2\end{array}$} & EG & 31 & 3.19 & 1.22 & \multirow{2}{*}{-1.126} & \multirow{2}{*}{0.265} \\
\hline & CG & 27 & 3.16 & 1.22 & & \\
\hline \multirow{2}{*}{$\begin{array}{l}\text { Situati- } \\
\text { onal } \\
\text { percep- } \\
\text { tion } 3\end{array}$} & $\mathrm{EG}$ & 31 & 3.26 & 1.41 & \multirow{2}{*}{-1.257} & \multirow{2}{*}{0.214} \\
\hline & CG & 27 & 3.70 & 1.27 & & \\
\hline \multirow{2}{*}{$\begin{array}{l}\text { Situati- } \\
\text { onal } \\
\text { percep- } \\
\text { tion } 4\end{array}$} & $\mathrm{EG}$ & 31 & 3.55 & 1.15 & \multirow{2}{*}{-1.326} & \multirow{2}{*}{0.190} \\
\hline & CG & 27 & 3.63 & 1.00 & & \\
\hline \multirow{2}{*}{$\begin{array}{l}\text { Situati- } \\
\text { onal } \\
\text { percep- } \\
\text { tion } 5\end{array}$} & $\mathrm{EG}$ & 31 & 3.11 & 1.12 & \multirow{2}{*}{-1.399} & \multirow{2}{*}{0.167} \\
\hline & CG & 27 & 4.04 & 1.19 & & \\
\hline \multirow{2}{*}{$\begin{array}{l}\text { Situati- } \\
\text { onal } \\
\text { percep- } \\
\text { tion } 6\end{array}$} & EG & 31 & 3.35 & 1.11 & \multirow{2}{*}{-1.163} & \multirow{2}{*}{0.250} \\
\hline & CG & 27 & 3.70 & 1.17 & & \\
\hline
\end{tabular}

$p=0.005$ for situational projection item 4 , and $p=0.037$ for situational projection item 5 .

\subsubsection{Comparison with expert group responses}

In order to verify whether the difference appeared in situational awareness capacity between the experimental group and the control group from the independent samples t-test of the second survey is a positive effect, the responses of the expert group and the averages of both experimental and control groups were compared. As shown in Table 6 below, the responses of the experimental group and the expert group were very similar in three items of situational projection (situation projection items 4, 5, and 6). 
Table 5. Results of post-test on situational projection

\begin{tabular}{|c|c|c|c|c|c|c|}
\hline $\begin{array}{c}\text { Depen- } \\
\text { dent } \\
\text { variable }\end{array}$ & Group & $\begin{array}{l}\# \text { of } \\
\text { sub- } \\
\text { jects }\end{array}$ & $\begin{array}{l}\text { Aver- } \\
\text { age }\end{array}$ & $\begin{array}{l}\text { Standard } \\
\text { deviation }\end{array}$ & $t$ & $p$ \\
\hline \multirow{2}{*}{$\begin{array}{c}\text { Situati- } \\
\text { onal } \\
\text { percep } \\
\text {-tion 1 }\end{array}$} & $\mathrm{EG}$ & 31 & 3.00 & 1.26 & \multirow[b]{2}{*}{-1.877} & \multirow[b]{2}{*}{0.066} \\
\hline & CG & 27 & 3.59 & 1.12 & & \\
\hline \multirow{2}{*}{$\begin{array}{c}\text { Situati- } \\
\text { onal } \\
\text { percep } \\
\text {-tion } 2\end{array}$} & EG & 31 & 3.55 & 1.15 & \multirow[b]{2}{*}{$2.619^{*}$} & \multirow[b]{2}{*}{0.011} \\
\hline & CG & 27 & 2.74 & 1.20 & & \\
\hline \multirow{2}{*}{$\begin{array}{c}\text { Situati- } \\
\text { onal } \\
\text { percep } \\
\text {-tion 3 }\end{array}$} & EG & 31 & 3.23 & 1.20 & \multirow[b]{2}{*}{-1.927} & \multirow[b]{2}{*}{0.059} \\
\hline & CG & 27 & 3.81 & 1.11 & & \\
\hline \multirow{2}{*}{$\begin{array}{c}\text { Situati- } \\
\text { onal } \\
\text { percep } \\
\text {-tion } 4\end{array}$} & EG & 31 & 3.52 & 1.12 & \multirow[b]{2}{*}{$2.892^{*}$} & \multirow[b]{2}{*}{0.005} \\
\hline & CG & 27 & 2.67 & 1.11 & & \\
\hline \multirow{2}{*}{$\begin{array}{c}\text { Situati- } \\
\text { onal } \\
\text { percep } \\
\text {-tion } 5\end{array}$} & $\mathrm{EG}$ & 31 & 3.35 & 1.11 & \multirow[b]{2}{*}{$2.141^{*}$} & \multirow[b]{2}{*}{0.037} \\
\hline & CG & 27 & 2.70 & 1.20 & & \\
\hline \multirow{2}{*}{$\begin{array}{c}\text { Situati- } \\
\text { onal } \\
\text { percep } \\
\text {-tion } 6\end{array}$} & EG & 31 & 3.35 & 1.36 & \multirow[b]{2}{*}{1.902} & \multirow[b]{2}{*}{0.062} \\
\hline & CG & 27 & 2.70 & 1.23 & & \\
\hline
\end{tabular}

For example, the average score of the expert group for situational projection item 4 was 2.70, whereas the average scores of the experimental group and the control group were 2.67 and 3.52, respectively, showing the similar answers of the experimental group and the expert group. The average score of the expert group for situational projection item 5 was 2.60, while the average scores of the experimental group and the control group were 2.70 and 3.35 , respectively, showing the similar answers of the experimental group and the expert group again. Moreover, the average score of the expert group for situational projection item 6 was 2.60, whereas the average scores of the experimental group and the control group were 2.70 and 3.35 , respectively, showing the
Table 6. Comparison with expert panel response

\begin{tabular}{c|c|c|c|c|c|c}
\hline & \multicolumn{2}{|c|}{ Control group } & \multicolumn{2}{|c|}{ Expert group } & \multicolumn{2}{|c}{$\begin{array}{c}\text { Experimental } \\
\text { group }\end{array}$} \\
\cline { 2 - 6 } & $\begin{array}{c}\text { Aver- } \\
\text { age }\end{array}$ & $\begin{array}{c}\text { Standard } \\
\text { deviation }\end{array}$ & $\begin{array}{c}\text { Aver- } \\
\text { age }\end{array}$ & $\begin{array}{c}\text { Standard } \\
\text { deviation }\end{array}$ & $\begin{array}{c}\text { Aver- } \\
\text { age }\end{array}$ & $\begin{array}{c}\text { Standard } \\
\text { deviation }\end{array}$ \\
\hline $\begin{array}{c}\text { Situati- } \\
\text { onal } \\
\text { percep- } \\
\text { tion 1 }\end{array}$ & 3.50 & 1.26 & 2.20 & 0.42 & 3.59 & 1.12 \\
\hline $\begin{array}{c}\text { Situati- } \\
\text { onal } \\
\text { percep- } \\
\text { tion 1 }\end{array}$ & 3.55 & 1.15 & 1.90 & 0.74 & 2.74 & 1.20 \\
\hline $\begin{array}{c}\text { Situati- } \\
\text { onal } \\
\text { percep- } \\
\text { tion 1 }\end{array}$ & 3.23 & 1.20 & 2.50 & 0.85 & 3.31 & 1.11 \\
\hline $\begin{array}{c}\text { Situati- } \\
\text { onal } \\
\text { percep- } \\
\text { tion 1 }\end{array}$ & 3.52 & 1.12 & 2.70 & 1.25 & 2.67 & 1.11 \\
\hline $\begin{array}{c}\text { Situati- } \\
\text { onal } \\
\text { percep- } \\
\text { tion 1 }\end{array}$ & 3.35 & 1.11 & 2.60 & 1.35 & 2.70 & 1.20 \\
\hline $\begin{array}{c}\text { Situati- } \\
\text { onal } \\
\text { percep- } \\
\text { tion 1 }\end{array}$ & 3.35 & 1.36 & 2.60 & 0.84 & 2.70 & 1.23 \\
\hline & & & & & & \\
\hline
\end{tabular}

similar answers of the experimental group and the expert group once again.

Given the above results, hypothesis 1 was rejected since learning the educational materials using the encoding techniques could not be said to have affected the situational perception factor as there was no significant difference found in the said factor between the experimental group and the control group from the second survey.

In the case of the situational comprehension item 1 in which a significant difference was found between the experimental group and the control group in the second survey, hypothesis 2 was rejected because the study could not confirm whether that was a positive effect or not as the answers of both groups were diffe 
rent from the that of the expert group.

In the case of the situational projection items 4 and 5 in which a significant difference was found between the two groups in the second survey, hypothesis 3 was accepted because the study could confirm the positive effect as the experimental group's responses were similar to those of the experts.

\section{CONCLUSION}

\subsection{Research summary and discussion}

The purpose of this study was to confirm whether learning emergency educational materials using encoding techniques has a positive effect on improving the situational awareness of student pilots during flying, who are majored in Aeronautical Science and Flight Operation at a domestic university and enrolled in the PPL program. The confirmed results are as follows.

First, according to the first survey (pre-test) results on situational awareness conducted before earning emergency education materials using the encoding technique, there was no difference found in three factors of situational awareness, such as situational perception, situational comprehension, and situational projection, between the experimental group and the control group.

Second, according to the comparative analysis results of the first (pre-test) and second (posttest) surveys, student pilots who learned emergency education materials using the encoding technique showed no change in situational perception among the three factors of situational awareness. Even though they did show a slight change in situational comprehension compared to the control group, it was difficult to say the difference was significant. However, they showed improvement in situational projection compared to the control group. Their situational projection got better than before learning using the encoding techniques. They even showed a level of situational projection similar to that of the expert group.

Therefore, this study is meaningful in that, along with flight training to acquire aircraft handling skills, it has verified that learning emergency materials to which the encoding techniques are applied makes student pilots who are majored in aeronautical science and flight operation at a domestic university and enrolled in the PPL program - good at situational projection during flying. It has also identified the possibility that situational awareness can be enhanced.

\subsection{Research limitations}

It is believed that this study has the following limitations.

First, since the research subjects were limited to those who are participating in the PPL program in Korea among the students who majored in Aeronautical Science and Flight Operation at a domestic university, students who are receiving the flight training overseas were not included in the study. There is a limitation in that this study was not able to confirm whether PPL programs in a foreign country includes an education curriculum on situation awareness.

Second, since this research was conducted among students who majored in Aeronautical Science and Flight Operation at a domestic university only; there is a limitation in that the age and previous education experiences of research subjects are similar. If a similar study can be conducted among student pilots from various institutions, such as general aviation and flight schools, the effects of using the encoding techniques on situational awareness of student pilots in the early stage of flight training will be verified in a more general and comprehensive manner.

Third, an online survey was conducted due to the influence of the coronavirus, and emergency education materials using encoding tech- 
niques were provided to the experimental group online. Further research will also be required to investigate whether a change occurs in situational awareness of student pilots in the early stage of training when these materials are explained and offered offline.

\section{References}

1. Kwon, B. H., "A study on correlation between pilot's situation awareness and knowledge structure", Ph.D. Thesis, Korea Aerospace University, Goyang, 2007.

2. Son, Y. W., Kim, Y. S. and Kim, C., "Commercial airline pilots' risk perception of emergency flight situation”, Journal of The Korean Society for Aviation and Aeronautics, 15(3), 2007, pp. 46-56.

3. Lee, J. M., "A reformulation of the conceptual foundations of psychology (2): Extending the concept of "Mind" and the extent of psychology, based on the perspectives of cognitive science", Journal of Korean Psychological Association, 26(2), 2007, pp. $1-38$.

4. Lee, H. S., "Testing for learning: The forward and backward effect of testing", Korean Journal of Educational Psychology, 31(4), 2017, pp. 819-845.

5. Lim, J. G., "The analysis of aircraft mishap in air force", Korean Journal of Aerospace and Environmental Medicine, 24(2), 2014, pp. 28-31.

6. Choi, D. H., "Brain-scientific understanding of learning strategies on encoding and their applications to the teaching and learning", Master's Degree, Seoul National University of Education, Seoul, 2018.

7. Choi, S. H., "A study on situation awareness of helicopter pilot", Ph.D. Thesis, Korea Aerospace University, Goyang, 2011.

8. Park, S. E., Son, Y. W., Kwon, B. H., Seol, J. W., Kim, Y. S., Kim, D. H., Kim, G. T. and
Jang, S. W., “Aviation Psychology", Hakjisa, Seoul, 2006, pp. 109-143.

9. Yang, D. G., "Dictionary of Psychology", Pakyoungsa, Seoul, 2018.

10. Goldstein, E. B., "Cognitive Psychology", CENGAGE, Seoul, 2019.

11. Anderson, J. R., "Cognitive Psychology and It's Implications", Ewha Woman University Press, Seoul, 2018.

12. Nevid, J. S., "Psychology; Concepts and Applications", Hakjisa CENGADE , Seoul, 2019.

13. Carol, L. A., "Desperately seeking SA", TAV Attack(TACSP 127-1), 32(3), 1992, pp. 5-6.

14. Craik, F. I. and Lockhart, R. S., "Levels of processing: A framework for memory research", Journal of Verbal Learning and Verbal Behavior, 11(6), 1972, pp. 671-684.

15. Endsley, M. R., "Design and evaluation for situation awareness enhancement", Proceeding of Human Factors Society 32nd Annual Meeting, Santa Monica, CA., 1988, pp. 97-101.

16. Endsley, M. R., "Toward a theory of situation awareness in dynamic system", Human Factors, 37, 1995, pp. 32-64.

17. Goh, J. and Wiegmann, D. A., "Relating flight experience and pilot's perceptions of decision-making skill”, In Proceedings of the 46th Annual Meeting of the Human Factors and Ergonomics Society, Baltimore, MD. 2002.

18. ICAO, DOC. 10004, Global Aviation Safety Plan 2017-2019, International Civil Aviation Organization, 2019.

19. Taylor, R. M., "Situation awareness rating technique (SART)", Symposium on Situational Awareness in Aerospace Operations, CP478, 1989.

20. Weinstein, C. and Mayer, R., "The Teaching of Learning Strategies", In: Wittrock, M., Ed., Handbook of Research on Teaching, Macmillan, New York, 1986, pp. 315-327. 